\title{
Chemistry and Agriculture
}

$\mathrm{T}$ HE thirty-eighth Bedson Lecture was delivered by Sir John Russell, director of the Rothamsted Experimental Station, on "Applications of Chemistry to Modern Food Production", at Armstrong College, Newcastle-on-Tyne, on May 21.

Sir John approached the problem by a short survey of British agriculture. His conclusions are : we are eating less bread but more meat, vegetables, butter, cheese to-day than in 1913, and although home production of milk, potatoes and vegetables is high, the home production of butter and flour is low, a matter of significance from the point of view of defence. The farmer, he said, must be judged on his own efficiency and not on the ultimate bulk production of agriculture, and statistics show that although there are fewer farmers now than in 1913, the output per person is greater and he feeds a greater number of persons than do the farmers of inost other countries.

The classical approach of chemistry to the problem of plant growth was to find a substitute for farmyard manure, and at the time this was first broached it was suggested that a mixture of simple salts in such a proportion that the ultimate analysis approximated to that of manure would be sufficient. This was only partly true; the simple salts were highly effective and were extensively used under the name of artificial fertilizers, but the optimum proportions could be ascertained only by field trial. Interesting consequences followed from the circumstance that these fertilizers contained not only the specified plant nutrient but various amounts of other elements also. Extensive use of chemical fertilizers pushed up production for foodstuffs even where the actual acreage under cultivation has fallen.

Less is known of the more complex problem of the actual elements necessary to plant growth and their action. Science is advancing along two lines of investigation : trial and error methods and systematic statistical investigation. With regard to the function of the necessary elements, a study of plant deficiency diseases has proved useful. Examples of the results are : the addition of borax in certain conditions causes better growth of certain plants; and traces of manganese, copper and other elements appear to be essential to good growth. Some plants will take up particular nutrients more readily than others, so that the correct choice of a fertilizer will lead to preferential growth of these plants.

The soil is now receiving attention from chemists. One method of attack is to carry out field experiments in different types of soil with the same groups of fertilizers and to correlate the results with those of chemical examination. The method is slow and has to be rigorously controlled on a statistical basis.

Finally, Sir John dealt with the organic constituents of manure and described how experiments are carried out from two directions: the investigation of extracts of manure and the use of known organic compounds in growth tests. Examples of compounds exercising a marked effect on growth are indoleacetic acid and naphthalene-acetic acid.

\section{Macculloch's Geological Map of Scotland}

$\mathrm{W}$ HEN Henry $T$. de la Beche was trying, in the early eighteen-thirties, to persuade the Government to allow him to undertake an official geological survey of Great Britain, he encountered many objections of a financial nature. Even in 1840, five years after the "Ordnance Geological Survey", as it was at first called, had been officially established, and de la Beche sought permission to spend the winter in London instead of in the field, a letter from the Board of Ordnance stated that the authorities had "adverted to what occurred in respect of the Scotch Geological Survey, and they desire that special care may be taken to prevent the occurrence of a similar fault in the English Survey".

As a result of the perusal of a Parliamentary paper dealing with the expenses of the "Mineralogical Survey of Scotland", submitted to the Commons in 1830, and of the minute books of the Highland and Agricultural Society of Scotland, Mĩ. V. A. Eyles has been able to show exactly what transpired in Scotland to make the authorities reluctant to give too free a hand to a man so enthusiastic and energetic as de la Beche.

The circumstances connected with the appointment of Dr. John Macculloch as geologist to the Trigono. metrical Survey, and the preparation of his geological map of Scotland, which was not published until 1836 , the year after his death, are outlined in a paper entitled "John Macculloch, F.R.S. and his Geological Map; an account of the first Geological Survey of
Scotland" (V. A. Eyles, Annals of S'cience, 2, 114$129 ; 1937)$. It appears that Macculloch's salary was to be $£ 2$ per day during the time he was at work, with an allowance of $£ 1$ a day for personal expenses, and $2 s$. for every mile he travelled. There was also an allowance of $£ 90$ per season for an assistant, but although no mention is made of the identity or the duties of an assistant, the pay was drawn for several years.

The travelling allowance gave rise to trouble with the Treasury, for in 1828 Macculloch charged for 7,764 miles of travel in 184 days. The auditors pointed out that, allowing for a journey from London to Glasgow, which accounted for 735 miles and four days, and for no work being done on Sundays, Macculloch must have travelled, on an average, 5l-52 miles a day, which was, the report continues, "a rapidity of travel, which would hardly allow much time for scientific observation".

It would be unfair to the memory of a great man to refer only to this aspect of his work, for he was hard working and competent, and, as Mr. Eyles points out, in spite of the difficulties arising from a lack of good topographical maps, Macculloch's geological map of Scotland has stood the test of time. It became the basis of all subsequent geological maps of that country, and there are still areas of which little more is known than was recorded more than a century ago by that versatile Guernsev-born Scotsman.

F. J. N. 